\title{
Ekhidna lutea gen. nov., sp. nov., a member of the phylum Bacteroidetes isolated from the South East Pacific Ocean
}

\author{
Correspondence \\ Philippe Lebaron \\ philippe.lebaron@obs-banyuls.fr
}

\author{
Karine Alain, ${ }^{1} \dagger$ Brian J. Tindall, ${ }^{2}$ Philippe Catala, ${ }^{1}$ Laurent Intertaglia ${ }^{1}$ \\ and Philippe Lebaron ${ }^{1}$
${ }^{1}$ Université Pierre et Marie Curie - Paris 6, CNRS, UMR7621, F-66650 Banyuls-sur-Mer, France
${ }^{2}$ DSMZ - Deutsche Sammlung von Mikroorganismen und Zellkulturen, Inhoffenstraße 7B, 38124 Braunschweig, Germany

\begin{abstract}
A novel aerobic, heterotrophic bacterium, designated BiosLi39 ${ }^{\top}$, was isolated from the South East Pacific Ocean. Cells were Gram-negative gliding rods forming yellow colonies on marine agar. The isolate was oxidase-, catalase- and alkaline phosphatase-positive and $\beta$-galactosidasenegative. Strain BiosLi39 $9^{\top}$ grew at $20-37^{\circ} \mathrm{C}$ (optimum $30{ }^{\circ} \mathrm{C}$ ), at $\mathrm{pH} 7.0-9.0$ (optimum pH 8.0) and with $20-60 \mathrm{~g} \mathrm{NaCl} \mathrm{I}^{-1}$ (optimum $30-50 \mathrm{~g} \mathrm{NaCl} \mathrm{I}^{-1}$ ). The fatty acids $(>1 \%)$ comprised iso$\mathrm{C}_{14: 0}$, iso- $\mathrm{C}_{15: 1} \mathrm{G}$, iso- $\mathrm{C}_{15: 0}$, anteiso- $\mathrm{C}_{15: 0}, \mathrm{C}_{15: 1} \mathrm{G}, \mathrm{C}_{15: 0}$, iso- $\mathrm{C}_{15: 0} 2-\mathrm{OH}$, iso- $\mathrm{C}_{16: 1} \mathrm{G}$, iso- $\mathrm{C}_{16: 0}$, iso- $\mathrm{C}_{16: 0} 3-\mathrm{OH}$, iso- $\mathrm{C}_{16: 0} 2-\mathrm{OH}$, iso- $\mathrm{C}_{17: 0} 3-\mathrm{OH}, \mathrm{C}_{17: 0} 2-\mathrm{OH}$ and three unidentified components with equivalent chain lengths of $17.87,18.10$ and 18.71. A significant proportion of the hydroxylated fatty acids are amide-linked. The lipid pattern indicated the presence of phosphatidylethanolamine, two unidentified aminolipids and three unidentified polar lipids. The strain contained menaquinone 7 as the sole respiratory lipoquinone and did not produce flexirubin-type pigments. The $\mathrm{G}+\mathrm{C}$ content of the genomic DNA was $37.2 \mathrm{~mol} \%$. Comparative 16S rRNA gene sequence analysis indicated that strain BiosLi39 ${ }^{\top}$ was distantly related to all of the representatives of the phylum Bacteroidetes. Its closest relative was Marinoscillum furvescens IFO $15994^{\top}$, with which it shared $92.5 \% 16 \mathrm{~S}$ rRNA gene sequence similarity. On the basis of genotypic, phenotypic and chemotaxonomic characteristics, we propose a novel genus and species, Ekhidna gen. nov., sp. nov., with type strain BiosLi39 ${ }^{\top}$ $\left(=\mathrm{DSM} 19307^{\top}=\right.$ CIP $109600^{\top}=$ OOB $\left.398^{\top}\right)$.
\end{abstract}

Members of the phylum Bacteroidetes have a worldwide distribution in marine and terrestrial ecosystems. They are particularly common and abundant in many freshwater and marine systems (Kirchman, 2002). Although all of the cultured strains of this group are Gram-negative chemoorganoheterotrophs, they display a high degree of biological diversity with respect to their biochemical and physiological properties and chemotaxonomic characteristics, which is also reflected in their genotypic diversity.

The taxonomy of this large group of bacteria, formerly classified as the group Cytophaga-Flavobacterium-Bacteroides

tPresent address: UMR6197, Laboratoire de Microbiologie des Environnements Extrêmes, IUEM, Technopôle Brest-Iroise, F-29280 Plouzané, France.

Abbreviation: ECL, equivalent chain length.

The GenBank/EMBL/DDBJ accession number for the 16S rRNA gene sequence of strain BiosLi39 ${ }^{\top}$ is AM746475.

A graph showing the effect of temperature on the maximum growth rate of strain BiosLi39 ${ }^{\top}$ is available with the online version of this paper.
(Olsen et al., 1994), has a long history of nomenclatural modifications and large sections are in need of taxonomic clarification. As an example, the differentiation between members of the genera Cytophaga, Flavobacterium and Flexibacter has been problematic because of the numerous phenotypic similarities between the representatives and because delineation relied for a long time mainly on the presence or absence of gliding motility, a feature that is now considered as a common ancestral property that may be lost by some organisms in the course of their evolution. The taxonomy of the phylum Bacteroidetes has been partially clarified by rRNA similarity studies (Paster et al., 1985; Gherna \& Woese, 1992; Nakagawa \& Yamasato, 1993, 1996; Bernardet et al., 1996; Nakagawa et al., 2002) and chemotaxonomic analyses (Dees et al., 1985; Nakagawa \& Yamasato, 1993, 1996).

During the last decade, many novel taxa belonging to this phylum have been characterized. In parallel, the general application of polyphasic taxonomy has led to taxonomic re-evaluation or reclassification of misclassified taxa 
(Vandamme et al., 1994; Bernardet et al., 1996; Nakagawa \& Yamasato, 1996; Johansen et al., 1999; Suzuki et al., 2001; Sakamoto et al., 2002). Nevertheless, the phylogenetic positions of many taxa are still not clear-cut (Suzuki et al., 2001; Bernardet et al., 2002) and the boundaries of classes and families, as well as the phenotypic and genotypic characteristics of these taxonomic levels, are still not well defined. In this study, a novel marine member, strain BiosLi39 ${ }^{\mathrm{T}}$, of the phylum Bacteroidetes is described.

In November-December 2004, seawater samples were collected in the oligotrophic waters of the South East Pacific Gyre (28 $32.176^{\prime}$ S $104^{\circ} 18.480^{\prime}$ W) during the BIOSOPE oceanographic cruise. A sample collected at a depth of $5 \mathrm{~m}\left(21{ }^{\circ} \mathrm{C}, 35.9 \%\right.$ salinity $)$ was used to inoculate marine broth (MB; Difco), which was incubated at $25{ }^{\circ} \mathrm{C}$. The enrichment was spread on marine agar (MA; Difco). Strain BiosLi39 ${ }^{\mathrm{T}}$ was isolated from a yellow colony by repeated streaking on MA. Stock cultures were stored at $-80{ }^{\circ} \mathrm{C}$ in $\mathrm{MB}$ supplemented with $5 \%(\mathrm{v} / \mathrm{v})$ DMSO or $35 \%(\mathrm{v} / \mathrm{v})$ glycerol.

The almost-complete 16S rRNA gene sequence (1368 bp) of the strain was obtained from a single colony as described elsewhere (Agogué et al., 2005); both strands were sequenced. The sequence was compared with those in available databases using BLAST (Altschul et al., 1990) and aligned with its nearest neighbours using CLUSTAL $x$ (Thompson et al., 1997). The alignment was refined manually using SEAVIEW (Galtier et al., 1996) based on an alignment generated in parallel with the RDP II sequence aligner (http://rdp8.cme.msu.edu/cgis/seq_align.cgi) before calculating identity percentages from 1325 unambiguously aligned nucleotides for a similarity matrix. Phylogenetic reconstructions were represented graphically using PHYLIP version 3.67 (http://evolution.genetics.washington.edu/ phylip/getme.html) on the basis of evolutionary distances (neighbour-joining method with Jukes and Cantor corrections) (Saitou \& Nei, 1987) and maximum likelihood (Felsenstein, 1981). The robustness of the inferred topologies was assessed by bootstrap analyses (Felsenstein, 1985) based on 1000 resamplings for the neighbour-joining method and 100 replications for the maximum-likelihood method. A phylogenetic tree reconstructed with the maximum-likelihood method is shown in Fig. 1. The $16 \mathrm{~S}$ rRNA gene sequence analysis revealed that strain BiosLi39 ${ }^{\mathrm{T}}$ belonged to the phylum Bacteroidetes. Within this lineage, strain BiosLi39 ${ }^{\mathrm{T}}$ formed a separate lineage within a robust cluster also containing Marinoscillum furvescens IFO $15994^{\mathrm{T}}$ (formerly described as '[Microscilla] furvescens'; Lewin, 1969) and Marinoscillum pacificum MRN461 ${ }^{\mathrm{T}}$, and high bootstrap values for this relationship were observed. The same relationships were recovered in a phylogenetic tree reconstructed with the neighbour-joining method (data not shown). Strain BiosLi39 $9^{\mathrm{T}}$ shared 92.5 and $91.1 \%$ $16 \mathrm{~S}$ rRNA gene sequence similarity with $M$. furvescens IFO $15994^{\mathrm{T}}$ and $M$. pacificum MRN461 ${ }^{\mathrm{T}}$, respectively. Other close phylogenetic neighbours were members of the genus Roseivirga (90.0-91.0\%), Fabibacter halotolerans
UST030901-097 ${ }^{\mathrm{T}} \quad(89.5 \%)$, Marivirga tractuosa IFO $15989^{\mathrm{T}}(89.0 \%)$ and Marivirga sericea IFO $15983^{\mathrm{T}}$ $(89.1 \%)$. Such low levels of 16S rRNA gene sequence similarity between strain BiosLi39 $9^{\mathrm{T}}$ and its nearest neighbours indicated that the isolate represented a novel genus within the phylum Bacteroidetes.

The DNA G $+\mathrm{C}$ content was determined by the Identification Service of the DSMZ (Braunschweig, Germany), by HPLC analysis of deoxyribonucleosides as described by Mesbah et al. (1989). The DNA G+C content of strain BiosLi39 ${ }^{\mathrm{T}}$ was $37.2 \mathrm{~mol} \%$, which was within the range typically reported for aerobic members of the phylum Bacteroidetes.

Colonies of strain BiosLi39 ${ }^{\mathrm{T}}$ were smooth, creamy and shiny with entire edges and bright yellow when grown on MA. After 4 days at $25^{\circ} \mathrm{C}$, colonies were $0.5 \mathrm{~mm}$ in diameter. Morphological characteristics of the cells were determined by light microscopy (AX70; Olympus) and transmission electron microscopy (H-7500; Hitachi) with negative staining using uranyl acetate (Raguénès et al., 1997). Gliding motility was determined using the hangingdrop method on cells grown at $30{ }^{\circ} \mathrm{C}$ in low nutrient medium $[0.1 \%(\mathrm{w} / \mathrm{v})$ marine broth solidified with $1 \%$ agar], as described by Bernardet et al. (2002). Cells of strain BiosLi39 $9^{\mathrm{T}}$ were Gram-negative, non-spore-forming, gliding, thin straight rods, $2.0-6.0 \mu \mathrm{m}$ in length and $0.3-$ $0.5 \mu \mathrm{m}$ in width in mid-exponential phase. Longer cells were observed during late stationary phase. The presence of flexirubin-type pigments was investigated by flooding colonies with $20 \% \mathrm{KOH}$ and then with acid, as described elsewhere (Reichenbach, 1989; Bernardet et al., 2002); a negative reaction that is characteristic of the absence of flexirubin was observed. The non-diffusive bright yellow colour was probably produced by carotenoid pigments, but no attempt was made to characterize them further.

To analyse respiratory quinones and polar lipids, strain BiosLi39 $9^{\mathrm{T}}$ was grown on MA at $30{ }^{\circ} \mathrm{C}$ for 5 days and checked for purity. Analyses of isoprenoid quinones and polar lipids were carried out by the Identification Service of the DSMZ by the two-stage method (Tindall, 1990a, b), using chloroform/methanol/water $(65: 25: 4)$ in the first dimension and chloroform/methanol/acetic acid/water $(80: 12: 15: 4)$ in the second dimension and with phosphatidylethanolamine serving as an internal reference point. Menaquinone 7 was the only respiratory quinone (100\%). Phosphatidylethanolamine was the only phospholipid and five other unidentified polar lipids, two containing amino groups, were also present (Fig. 2). It should be noted that the $\mathrm{Rf}$ values of the unidentified lipids need to be documented by means of an image of the chromatogram in order to allow comparison with any future work. Phosphosphingolipids were not produced. The presence of phosphatidylethanolamine as the sole predominant diglyceride-based phospholipid, together with an array of various amino acid-based lipids, is typical of polar lipid patterns of most aerobic members of the phylum Bacteroidetes. 


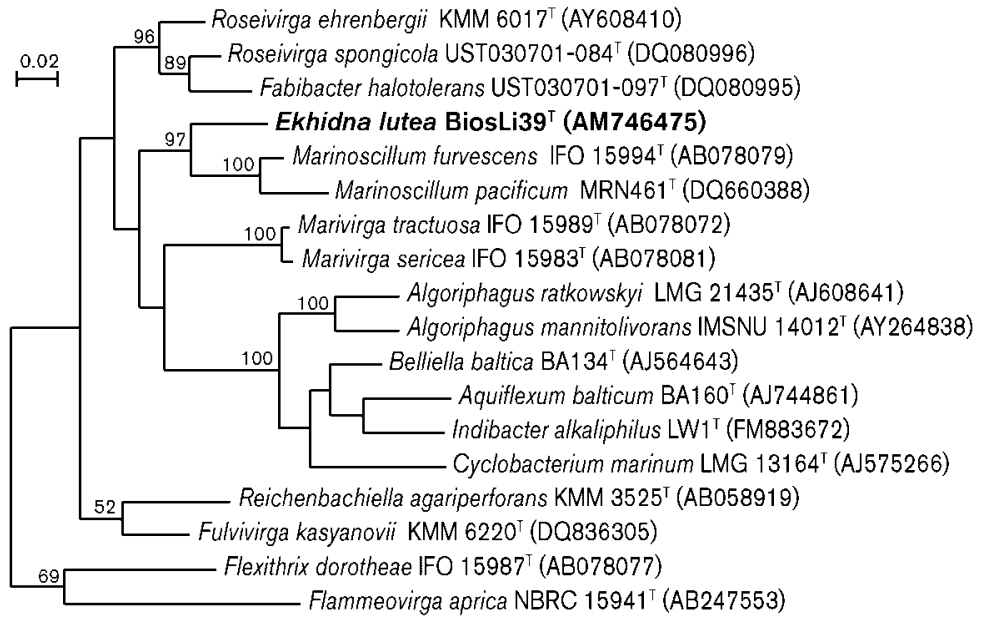

Fig. 1. Maximum-likelihood dendrogram based on 16S rRNA gene sequences showing the phylogenetic relationships between strain BiosLi39 ${ }^{\top}$ and some related taxa. Bootstrap values $(>50 \%)$ based on 100 replicates are shown at branch nodes. Bar, 0.02 substitutions per nucleotide position.
The determination of the whole-cell fatty acid composition of strain BiosLi39 ${ }^{\mathrm{T}}$ was performed on cultures grown at $30{ }^{\circ} \mathrm{C}$ for $72 \mathrm{~h}$ on MA. This analysis was initially carried out at the DSMZ according to the standard protocol of the Microbial Identification System (MIDI Inc., 2001). Extracts were analysed using a Hewlett Packard model HP6890A gas chromatograph equipped with a flame-ionization detector, as described by Kämpfer \& Kroppenstedt (1996). However, a number of peaks were not identified and further studies were undertaken using the two-stage method of Labrenz et al. (1998) that detects fatty acids with ester links (stage 1) and ester and non-ester (amide) links (stage 2). Fatty acid peaks were initially identified using the MIDI system using

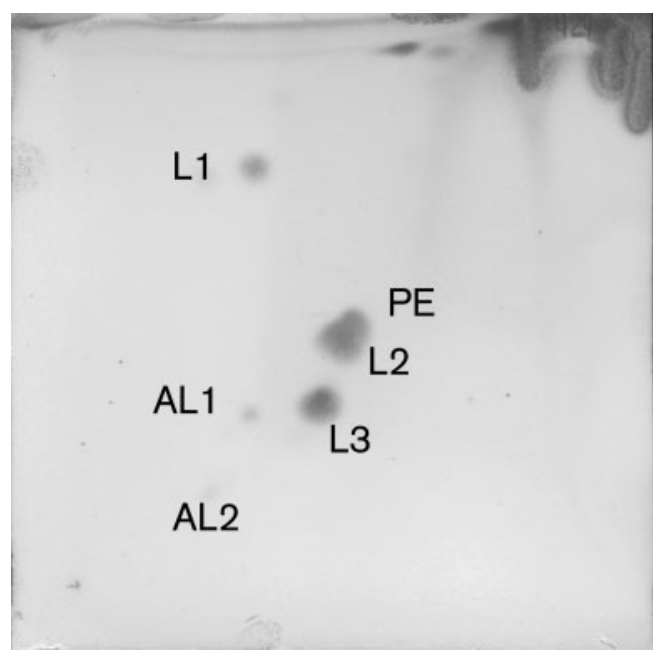

Fig. 2. Thin-layer chromatogram of the polar lipids of strain BiosLi39 ${ }^{\top}$. AL, unidentified aminolipid; $L$, unidentified polar lipid; $\mathrm{PE}$, phosphatidylethanolamine. TLC was performed on silica gel thin layers using chloroform/methanol/water $(65: 25: 4)$ in the first dimension and chloroform/methanol/acetic acid/water $(80: 12: 15: 4)$ in the second dimension and with phosphatidylethanolamine serving as an internal reference point. the TSBA 5.0 peak-naming table and checked by mass spectrometry using a Varian CP-3800 GC coupled to a Varian 320-MS mass spectrometer and fitted with a Varian CP-8400 auto-sampler. The presence of unsaturated fatty acids was confirmed by bromination (Brian \& Gardner, 1968), the presence of 3-OH fatty acids by the presence of dominant peaks at $m / z 103$ and the presence of 2-OH fatty acids by the presence of peaks at $m / z \mathrm{M}^{+}-59$ and $\mathrm{m} / z 90$. The fatty acids are reported in Table 1, with a differentiation between only ester-linked fatty acids and both esterlinked and amide-linked fatty acids. Briefly, the following observations were made. Summed feature 3 (iso- $\mathrm{C}_{15: 0} 2$ $\mathrm{OH}$ and/or $\mathrm{C}_{16: 1} \omega 7 c$ ) was shown by mass spectrometry and the fact that it was not affected by bromination suggested that it comprises iso- $\mathrm{C}_{15: 0} 2-\mathrm{OH}$. The fact that increased levels of this fatty acid and number of the other $2-\mathrm{OH}$ and $3-\mathrm{OH}$ fatty acids were released in higher concentrations only after hydrolysis under conditions that released amide-linked fatty acids is consistent with the presence of amide-linked 2-OH and 3-OH fatty acids being present in capnine-like compounds (Godchaux \& Leadbetter, 1984). This is also consistent with polar lipid patterns where lipids that do not stain with any of the 'normal' spray reagents have Rf values similar to authentic capnine derivatives in the same solvent systems (B. J. Tindall, unpublished), although further structural work is needed to clarify the structure of the lipids labelled L1, L2 and L3 (Fig. 2). Amide-linked 3-OH fatty acids have also been shown to be present in the aminolipids of Flavobacterium johnsoniae (Cytophaga johnsonae) (Kawazoe et al., 1991). A fatty acid with an equivalent chain length (ECL) of 16.863 was identified by the peak-naming table as $\mathrm{C}_{17: 1} \omega 6 c$, but was clearly a $\mathrm{C}_{16: 0} 2-\mathrm{OH}$ fatty acid, which was tentatively identified as iso- $\mathrm{C}_{16: 0} 2-\mathrm{OH}$ on the basis of its ECL (this fatty acid is not included in the peak-naming tables of the MIDI system that were available). A peak with an ECL of 14.814 was not identified by the MIDI system, but was shown to be a $\mathrm{C}_{15: 1}$ isomer by mass spectrometry. Preliminary structural elucidation suggests that the double bond in this compound is located at the same position as in 
Table 1. Whole-cell fatty acid profiles of strain BiosLi39 ${ }^{\top}$ and its closest phylogenetic neighbours

Strains: 1, Ekhidna lutea gen. nov., sp. nov. BiosLi39 ${ }^{\mathrm{T}}$; 2, Marinoscillum furvescens DSM $4134^{\mathrm{T}}$ (Seo et al., 2009); 3, Marinoscillum pacificum MRN $461^{\mathrm{T}}=\mathrm{JCM} 1406^{\mathrm{T}}$ (Seo et al., 2009). Column A shows only ester-linked fatty acids. Column B shows both ester-linked fatty acids and amide-linked fatty acids. Values in bold represent hydroxy fatty acids that are ester- and amide-linked. tr, Trace; - , not detected/not reported.

\begin{tabular}{|c|c|c|c|c|}
\hline \multirow[t]{2}{*}{ Fatty acid (\%) } & \multicolumn{2}{|c|}{1} & \multirow[t]{2}{*}{2} & \multirow[t]{2}{*}{3} \\
\hline & A & B & & \\
\hline iso- $\mathrm{C}_{14: 0}$ & 1.6 & 1.0 & - & - \\
\hline $\mathrm{C}_{14: 0}$ & - & - & 1.5 & 1.1 \\
\hline $\mathrm{C}_{14: 0} 2-\mathrm{OH}$ & - & - & 3.9 & 2.6 \\
\hline iso- $\mathrm{C}_{15: 1} \mathrm{G}$ & 29.3 & 23.4 & $\operatorname{tr}$ & 3.2 \\
\hline iso- $\mathrm{C}_{15: 0}$ & 32.7 & 27.9 & 19.8 & 8.5 \\
\hline anteiso- $\mathrm{C}_{15: 0}$ & 3.0 & 2.2 & - & - \\
\hline $\mathrm{C}_{15: 1} \mathrm{G}^{*}$ & 0.0 & 2.5 & - & - \\
\hline$C_{15: 0}$ & 3.5 & 2.8 & $\operatorname{tr}$ & 0.9 \\
\hline iso- $\mathrm{C}_{15: 0} 2-\mathrm{OH} \dagger$ & 6.8 & 12.3 & - & - \\
\hline $\mathrm{C}_{15: 0} 2-\mathrm{OH}$ & 0.3 & 0.5 & $\operatorname{tr}$ & 1.5 \\
\hline iso- $\mathrm{C}_{16: 1} \mathrm{G}$ & 4.6 & 5.0 & - & - \\
\hline iso- $\mathrm{C}_{16: 0}$ & 2.8 & 2.5 & 1.9 & 3.2 \\
\hline $\mathrm{C}_{16: 1} \omega 5 c$ & - & - & 21.6 & 28.5 \\
\hline $\mathrm{C}_{16: 0}$ & 1.8 & 0.9 & 2.6 & 3.5 \\
\hline iso- $\mathrm{C}_{16: 0} 3-\mathrm{OH}$ & 1.6 & 1.5 & - & - \\
\hline iso- $\mathrm{C}_{16: 0} 2-\mathrm{OH} \ddagger$ & 0.8 & 1.4 & - & - \\
\hline $\mathrm{C}_{16: 0} 2-\mathrm{OH}$ & - & - & $\operatorname{tr}$ & 1.2 \\
\hline $\mathrm{C}_{16: 0} 3-\mathrm{OH}$ & - & - & 1.2 & 1.9 \\
\hline iso- $\mathrm{C}_{17: 0}$ & - & - & $\operatorname{tr}$ & 1.0 \\
\hline $\mathrm{C}_{17: 1} \omega 6 \$$ & - & - & $\operatorname{tr}$ & 1.8 \\
\hline iso- $\mathrm{C}_{17: 0} 3-\mathrm{OH}$ & 4.0 & 7.3 & 4.1 & 9.8 \\
\hline $\mathrm{C}_{17: 0} 2-\mathrm{OH}$ & 0.6 & 1.3 & - & - \\
\hline $\mathrm{C}_{17: 0} 3-\mathrm{OH}$ & 1.2 & 0.7 & $\operatorname{tr}$ & 1.0 \\
\hline \multicolumn{5}{|l|}{ Summed featuresll } \\
\hline 3 & - & - & 34.8 & 22.2 \\
\hline 4 & - & - & $\operatorname{tr}$ & 1.0 \\
\hline \multicolumn{5}{|l|}{ Unknown ECLs } \\
\hline 14.959 & - & - & 1.3 & 1.1 \\
\hline 17.87 & 0.0 & 3.2 & - & - \\
\hline 18.10 & 2.2 & 1.3 & - & - \\
\hline 18.71 & 3.0 & 2.2 & & \\
\hline
\end{tabular}

${ }^{*}$ Not identified by the MIDI system.

$\dagger$ Identified as summed feature 3 (iso- $\mathrm{C}_{15: 0} 2-\mathrm{OH}$ and/or $\mathrm{C}_{16: 1} \omega 7 c$ ) by the MIDI system.

¥Identified as $\mathrm{C}_{17: 1} \omega 6 c$ by the MIDI system.

$\$$ May be incorrectly identified by the MIDI system.

IISummed features represent two or three fatty acids that cannot be separated by the Microbial Identification System. Summed feature 3 consisted of iso- $\mathrm{C}_{15: 0} 2-\mathrm{OH}$ and/or $\mathrm{C}_{16: 1} \omega 7 \mathrm{c}$. Summed feature 4 consisted of iso- $\mathrm{C}_{17: 1} \mathrm{I}$ and/or anteiso- $\mathrm{C}_{17: 1} \mathrm{~B}$.

the compounds identified as iso- $\mathrm{C}_{15: 1} \mathrm{G}$ and iso- $\mathrm{C}_{16: 0} \mathrm{G}$, which suggests that they are part of a (chemically) homologous series. The novel fatty acid that is not listed in the MIDI Sherlock peak-naming table is labelled $\mathrm{C}_{15: 1}$ G. This information, together with the absence of significant quantities of unsaturated fatty acids with alternative stereochemistry of the double bond, indicates that $\mathrm{C}_{15: 1} \mathrm{G}$ exists in strain BiosLi39 ${ }^{\mathrm{T}}$, together with appropriate enzymes and genes. Further work on the identification of these fatty acids is in progress.

Unless stated otherwise, physiological characterization of strain BiosLi39 ${ }^{\mathrm{T}}$ was performed in triplicate in $\mathrm{MB}$ in the dark and aerobically under agitation. Growth was routinely monitored by measuring the increase in optical density at $600 \mathrm{~nm}$ using a spectrophotometer. Cell numbers were determined by flow cytometry in order to calculate calibration curves. Growth rates were calculated using linear regression analysis with five to nine points along the logarithmic portions of the resulting growth curves. Growth was tested at $9,15,20,25,30,33,37,40$ and $44{ }^{\circ} \mathrm{C}$ on MB medium. The novel isolate was mesophilic and grew at $20-37{ }^{\circ} \mathrm{C}$ (optimum $30{ }^{\circ} \mathrm{C}$; Supplementary Fig. S1, available in IJSEM Online). No growth was observed at 15 and $40{ }^{\circ}$ C. Growth at $\mathrm{pH} 4.0-10.0$ (at intervals of one $\mathrm{pH}$ unit) was tested at $30{ }^{\circ} \mathrm{C}$ in $\mathrm{MB}$ after adjustment to the required $\mathrm{pH}$ as described elsewhere (Alain et al., 2002). The $\mathrm{pH}$ range for growth was rather narrow ( $\mathrm{pH} 7.0-9.0)$ with a marked optimum at $\mathrm{pH} 8.0$, which is close to that of seawater. Growth with 2, 5, 10, 20, 30, 40, 50, 60,70 and $90 \mathrm{~g} \mathrm{NaCl} \mathrm{l}^{-1}$ was tested at $30{ }^{\circ} \mathrm{C}$ in MB. Growth was observed with 20-60 $\mathrm{g} \mathrm{NaCl}^{-1}$ (optimum 30-50 g NaCl $\mathrm{l}^{-1}$ ) and no growth was observed at 10 and $70 \mathrm{~g} \mathrm{NaCl}^{-1}$. This experiment demonstrated that strain BiosLi39 ${ }^{\mathrm{T}}$ is a general marine-type halophile.

Strain BiosLi39 ${ }^{\mathrm{T}}$ was found to be aerobic. Conventional phenotypic tests including those for oxidase, catalase and nitrate reductase were performed according to standard methods (Smibert \& Krieg, 1994). The isolate was catalaseand oxidase-positive and did not reduce nitrate. Biochemical tests were performed at $30{ }^{\circ} \mathrm{C}$ using the API ZYM system (bioMérieux), according to the manufacturer's instructions, using cells swabbed from the surface of MA and suspended in half-strength artificial seawater (Sigma). Supplementary biochemical tests were also performed using the API 20NE system (bioMérieux), according to the manufacturer's instructions. Substrate utilization was investigated as described elsewhere (Alain et al., 2008). In summary, negative reactions were observed for gelatinase, urease, arginine dihydrolase, indole- and $\beta$-galactosidase production and a positive reaction was observed for glucose fermentation. Strain BiosLi39 ${ }^{\mathrm{T}}$ was able to hydrolyse aesculin, but not agar, cellulose (filter paper), gelatin or urea. Strain BiosLi39 ${ }^{\mathrm{T}}$ produced alkaline phosphatase, esterase (C4), esterase lipase (C8), cystine arylamidase, leucine arylamidase, valine arylamidase, trypsin, $\alpha$-chymotrypsin, acid phosphatase and naphthol-AS-BI-phosphohydrolase, but not lipase (C14), $\alpha$-fucosidase, $\alpha$-galactosidase, $\beta$-galactosidase, $\alpha$-glucosidase, $\beta$-glucosidase, $\alpha$-mannosidase or $N$-acetyl- $\beta$-glucosaminidase. Strain BiosLi39 ${ }^{\mathrm{T}}$ assimilated citric acid, malic acid and phenylacetic acid and grew on yeast extract and peptone. 
Antibiotic sensitivity tests were performed with susceptibility discs (Bio-Rad) or filter-paper discs impregnated with different antibiotics on $\mathrm{MA}$ at $30^{\circ} \mathrm{C}$ for 1 week. Susceptibility was scored for zone diameters more than $10 \mathrm{~mm}$. Strain BiosLi39 ${ }^{\mathrm{T}}$ was sensitive to vancomycin, rifampicin, tetracycline, penicillin, polymyxin $\mathrm{B}$ and ciprofloxacin and was resistant to oxacillin.

Strain BiosLi39 ${ }^{\mathrm{T}}$ is most closely phylogenetically related to members of the genus Marinosillum, family 'Flexibacteraceae', and more distantly related to members of the genera Roseivirga, Fabibacter, Reichenbachiella and Fulvivirga, family 'Flammeovirgaceae'. Characteristics that differentiate strain BiosLi $39^{\mathrm{T}}$ from representatives of these genera are given in Table 2. In brief, in addition to phylogenetic distance, strain BiosLi39 ${ }^{\mathrm{T}}$ can be distinguished from its closest relatives by a number of genotypic and phenotypic features, including gliding motility, colony pigmentation, fatty acid profile, some enzyme activities, inability to degrade some high-molecular-mass compounds and genomic DNA G+C content. The value of the chemotaxonomic data in differentiating a new genus from the genera most closely related to strain BiosLi39 $39^{\mathrm{T}}$ is limited because there is a need for comprehensive studies on these and related taxa and on the identity of some fatty acids previously reported. Nevertheless, major differences can be observed in the fatty acid profile of strain BiosLi39 ${ }^{\mathrm{T}}$ and those of its two closest relatives.

In conclusion, in view of all the above-mentioned distinctive features, we propose that strain BiosLi39 ${ }^{\mathrm{T}}$ be assigned to a novel genus and species, for which the name Ekhidna lutea gen. nov., sp. nov. is proposed.

\section{Description of Ekhidna gen. nov.}

Ekhidna (E'khid.na. N.L. fem. n. Ekhidna a sea nymphdragon of Greek mythology producing slime, referring to the creaminess and smoothness of the colonies).

Cells are Gram-negative, non-spore-forming, rod-shaped and motile by gliding. Aerobic and chemoorganoheterotrophic. Mesophilic. Neutrophilic. Grow best at $\mathrm{NaCl}$ concentrations close to marine salinity. Oxidase-, catalaseand alkaline phosphatase-positive. The predominant quinone is MK-7. The fatty acid profile comprises exclusively ester-linked fatty acids (iso- $\mathrm{C}_{14: 0}$, iso- $\mathrm{C}_{15: 1} \mathrm{G}$, iso- $\mathrm{C}_{15: 0}$, anteiso- $\mathrm{C}_{15: 0}, \mathrm{C}_{15: 0}$, iso- $\mathrm{C}_{16: 1}$, iso- $\mathrm{C}_{16: 0}$, iso- $\mathrm{C}_{16: 0} 3-\mathrm{OH}$, unknown ECL 18.10 and unknown ECL 18.71) and esterand amide-linked fatty acids (iso- $\mathrm{C}_{15: 1} \mathrm{G}$, iso- $\mathrm{C}_{15: 0} 2-\mathrm{OH}$, iso- $\mathrm{C}_{16: 0} \quad 2-\mathrm{OH}$, iso- $\mathrm{C}_{17: 0} \quad 3-\mathrm{OH}, \mathrm{C}_{17: 0} \quad 2-\mathrm{OH}$ and unknown ECL 17.87). The polar lipid pattern comprises phosphatidylethanolamine, two unidentified aminolipids and three unidentified polar lipids. The Rf values of the unidentified compounds are shown in Fig. 2. Affiliated to the phylum Bacteroidetes (16S rRNA gene sequence analysis). The DNA G $+\mathrm{C}$ content is $37.2 \mathrm{~mol} \%$. The type species is Ekhidna lutea.

\section{Description of Ekhidna lutea sp. nov.}

Ekhidna lutea (lu'te.a. L. fem. adj. lutea gold yellow, the colour of the colonies on marine agar).

In addition to the characters described for the genus, displays the following characteristics. Colonies on MA medium are smooth, convex, brilliant with entire edges and intensely yellow. Flexirubin-type pigments are not

Table 2. Characteristics differentiating strain BiosLi39 ${ }^{\top}$ from closely related taxa

Taxa: 1, Ekhidna lutea sp. nov. BiosLi39 ${ }^{\mathrm{T}} ; 2$, Marinoscillum furvescens LMG $13023^{\mathrm{T}} ; 3$, Marinoscillum pacificum MRN $461^{\mathrm{T}} ; 4$, Roseivirga ehrenbergii KMM $6017^{\mathrm{T}} ; 5$, Fabibacter halotolerans UST030701-097 ${ }^{\mathrm{T}}$; 6, Reichenbachiella agariperforans KMM $3525^{\mathrm{T}} ; 7$, Fulvivirga kasyanovii KMM $6220^{\mathrm{T}}$. Data were taken from Lau et al. (2006), Nedashkovskaya et al. (2003, 2005, 2007), Seo et al. (2009) and this study. A, Apricot; B, brown; O, orange; P, pink; Y, yellow; +, positive; -, negative; ND, not determined.

\begin{tabular}{|c|c|c|c|c|c|c|c|}
\hline Characteristic & 1 & 2 & 3 & 4 & 5 & 6 & 7 \\
\hline Gliding motility & + & + & + & - & + & + & + \\
\hline Pigmentation & $\mathrm{Y}$ & $\mathrm{O}$ & $\mathrm{A}$ & $\mathrm{P}$ & $\mathrm{P}$ & $\mathrm{O}$ & $\mathrm{PB}$ \\
\hline Flexirubin & - & - & - & - & - & + & - \\
\hline \multicolumn{8}{|l|}{ Conditions for growth } \\
\hline Range $(\% \mathrm{NaCl})$ & $2-6$ & $0.4-9.3$ & $0.4-5.4$ & $1-8$ & $0-12$ & $1-6$ & $0-10$ \\
\hline Range $\left({ }^{\circ} \mathrm{C}\right)$ & $20-37$ & $15-45$ & $15-40$ & $4-39$ & $12-36$ & $4-35$ & $12-44$ \\
\hline$\beta$-Galactosidase & - & - & - & + & + & $\mathrm{ND}$ & + \\
\hline \multicolumn{8}{|l|}{ Hydrolysis of: } \\
\hline Agar & - & - & - & - & - & + & - \\
\hline Gelatin & - & + & - & + & - & + & + \\
\hline \multicolumn{8}{|l|}{ Production of: } \\
\hline Indole & - & - & + & - & - & - & - \\
\hline Acid from glucose & - & - & - & - & + & - & - \\
\hline 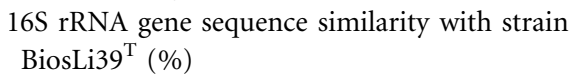 & 100 & 92.5 & 91.1 & 91.0 & 89.5 & 89.3 & 88.8 \\
\hline DNA G $+C$ content $(\mathrm{mol} \%)$ & 37.2 & 44.0 & 41.5 & 40.2 & 42.5 & 44.5 & 59.9 \\
\hline
\end{tabular}


produced. Grows on yeast extract and peptone. Grows at 20-37 ${ }^{\circ} \mathrm{C}$ (optimum $30{ }^{\circ} \mathrm{C}$ ), at $\mathrm{pH} 7.0-9.0$ (optimum $\mathrm{pH}$ 8.0) and with 20-60 $\mathrm{g} \mathrm{NaCl} \mathrm{l}^{-1}$ (optimum 30-50 g

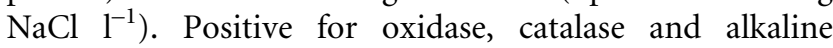
phosphatase, but negative for $\beta$-galactosidase, gelatinase, urease and arginine dihydrolase. Does not reduce nitrate. Does not produce indole. Hydrolyses aesculin, but not agar, cellulose (filter paper), gelatin or urea. Does not produce acid from glucose. Produces esterase (C4), esterase lipase (C8), cystine arylamidase, leucine arylamidase, valine arylamidase, trypsin, $\alpha$-chymotrypsin, acid phosphatase and naphthol-AS-BI-phosphohydrolase, but not lipase (C14), $\alpha$-fucosidase, $\alpha$-galactosidase, $\beta$-galactosidase, $\alpha$ glucosidase, $\beta$-glucosidase, $\alpha$-mannosidase or $N$-acetyl- $\beta$ glucosaminidase. Assimilates citric acid, malic acid and phenylacetic acid. The DNA $\mathrm{G}+\mathrm{C}$ content of the type strain is $37.2 \mathrm{~mol} \%$.

The type strain, BiosLi39 ${ }^{\mathrm{T}}\left(=\mathrm{DSM} 19307^{\mathrm{T}}=\mathrm{CIP} 109600^{\mathrm{T}}\right.$ $=\mathrm{OOB} 398^{\mathrm{T}}$ ), was isolated from marine waters of the South East Pacific Gyre.

\section{Acknowledgements}

We acknowledge Professor J. P. Euzéby for support with the Latin etymologies of the genus and species names. We thank the captain and crew of the NO L'Atalante and the chief scientist of the BIOSOPE oceanographic cruise. This work was financially supported by the Equipe Mixte de Recherche linking the Universite Pierre et Marie Curie and the Centre National de la Recherche Scientifique to the Pierre Fabre Laboratories. It was also partly funded by the French programme PICOFUNPAC (ANR Biodiversité grant number 06BDIV-013).

\section{References}

Agogué, H., Casamayor, E. O., Bourrain, M., Obernosterer, I., Joux, F., Herndl, G. J. \& Lebaron, P. (2005). A survey on bacteria inhabiting the sea surface microlayer of coastal ecosystems. FEMS Microbiol Ecol 54, 269-280.

Alain, K., Querellou, J., Lesongeur, F., Pignet, P., Crassous, P., Raguénès, G., Cueff, V. \& Cambon-Bonavita, M.-A. (2002). Caminibacter hydrogeniphilus gen. nov., sp. nov., a novel thermophilic, hydrogen-oxidizing bacterium isolated from an East Pacific Rise hydrothermal vent. Int J Syst Evol Microbiol 52, 1317-1323.

Alain, K., Intertaglia, L., Catala, P. \& Lebaron, P. (2008). Eudoraea adriatica gen. nov. sp. nov., a novel marine bacterium of the family Flavobacteriaceae. Int J Syst Evol Microbiol 58, 2275-2281.

Altschul, S. F., Gish, W., Miller, W., Myers, E. \& Lipman, D. (1990). Basic local alignment search tool. J Mol Biol 215, 403-410.

Bernardet, J.-F., Segers, P., Vancanneyt, M., Berthe, F., Kersters, K. \& Vandamme, P. (1996). Cutting a Gordian knot: emended classification and description of the genus Flavobacterium, emended description of the family Flavobacteriaceae, and proposal of Flavobacterium hydatis nom. nov. (basonym, Cytophaga aquatilis Strohl and Tait 1978). Int J Syst Bacteriol 46, 128-148.

Bernardet, J.-F., Nakagawa, Y. \& Holmes, B. for the Subcommittee on the taxonomy of Flavobacterium and Cytophaga-like bacteria of the International Committee on Systematics of Prokaryotes (2002). Proposed minimal standards for describing new taxa of the family Flavobacteriaceae and emended description of the family. Int $J$ Syst Evol Microbiol 52, 1049-1070.

Brian, B. L. \& Gardner, E. W. (1968). A simple procedure for detecting the presence of cyclopropane fatty acids in bacterial lipids. Appl Microbiol 16, 549-552.

Dees, S. B., Carlone, G. M., Hollis, D. \& Moss, C. W. (1985). Chemical and phenotypic characteristics of Flavobacterium thalpophilum compared with those of other Flavobacterium and Sphingobacterium species. Int J Syst Bacteriol 35, 16-22.

Felsenstein, J. (1981). Evolutionary trees from DNA sequences: a maximum likelihood approach. J Mol Evol 17, 368-376.

Felsenstein, J. (1985). Confidence limits on phylogenies: an approach using the bootstrap. Evolution 39, 783-791.

Galtier, N., Gouy, M. \& Gautier, C. (1996). SEAVIEW and PHYLO_WIN: two graphic tools for sequence alignment and molecular phylogeny. Comput Appl Biosci 12, 543-548.

Gherna, R. \& Woese, C. R. (1992). A partial phylogenetic analysis of the 'Flavobacter-Bacteroides' phylum: basis for taxonomic restructuring. Syst Appl Microbiol 15, 513-521.

Godchaux, W., III \& Leadbetter, E. R. (1984). Sulfonolipids of gliding bacteria. Structure of the $\mathrm{N}$-acylaminosulfonates. J Biol Chem 259, 2982-2990.

Johansen, J. E., Nielsen, P. \& Sjøholm, C. (1999). Description of Cellulophaga baltica gen. nov., sp. nov. and Cellulophaga fucicola gen. nov., sp. nov. and reclassification of [Cytophaga] lytica to Cellulophaga lytica gen. nov., comb. nov. Int J Syst Bacteriol 49, 1231-1240.

Kämpfer, P. \& Kroppenstedt, R. M. (1996). Numerical analysis of fatty acid patterns of coryneform bacteria and related taxa. Can $J$ Microbiol 42, 989-1005.

Kawazoe, R., Okuyama, H., Reichardt, W. \& Sasaki, S. (1991). Phospholipids and a novel glycine-containing lipoamino acid in Cytophaga johnsonae Stanier strain C21. J Bacteriol 173, 5470-5475.

Kirchman, D. L. (2002). The ecology of Cytophaga-Flavobacteria in aquatic environments. FEMS Microbiol Ecol 39, 91-100.

Labrenz, M., Collins, M. D., Lawson, P. A., Tindall, B. J., Braker, G. \& Hirsch, P. (1998). Antarctobacter heliothermus gen. nov., sp. nov., a budding bacterium from hypersaline and heliothermal Ekho Lake. Int J Syst Bacteriol 48, 1363-1372.

Lau, S. C. K., Tsoi, M. M. Y., Li, X., Plakhotnikova, I., Dobretsov, S., Wu, M., Wong, P.-K., Pawlik, J. R. \& Qian, P.-Y. (2006). Description of Fabibacter halotolerans gen. nov., sp. nov. and Roseivirga spongicola sp. nov., and reclassification of [Marinicola] seohaensis as Roseivirga seohaensis comb. nov. Int J Syst Evol Microbiol 56, 1059-1065.

Lewin, R. A. (1969). A classification of flexibacteria. J Gen Microbiol 58, 189-206.

Mesbah, M., Premachandran, U. \& Whitman, W. B. (1989). Precise measurement of the $\mathrm{G}+\mathrm{C}$ content of deoxyribonucleic acid by highperformance liquid chromatography. Int J Syst Bacteriol 39, 159-167.

MIDI Inc. (2001). Sherlock Microbial Identification System. Newark, DE: MIDI Inc.

Nakagawa, Y. \& Yamasato, K. (1993). Phylogenetic diversity of the genus Cytophaga revealed by $16 \mathrm{~S}$ rRNA sequencing and menaquinone analysis. J Gen Microbiol 139, 1155-1161.

Nakagawa, Y. \& Yamasato, K. (1996). Emendation of the genus Cytophaga and transfer of Cytophaga agarovorans and Cytophaga salmonicolor to Marinilabilia gen. nov.: phylogenetic analysis of the Flavobacterium-Cytophaga complex. Int J Syst Bacteriol 46, 599-603.

Nakagawa, Y., Sakane, T., Suzuki, M. \& Hatano, K. (2002). Phylogenetic structure of the genera Flexibacter, Flexithrix, and 
Microscilla deduced from $16 \mathrm{~S}$ rRNA sequence analysis. J Gen Appl Microbiol 48, 155-165.

Nedashkovskaya, O. I., Suzuki, M., Vysotskii, M. V. \& Mikhailov, V. V. (2003). Reichenbachia agariperforans gen. nov., sp. nov., a novel marine bacterium in the phylum Cytophaga-FlavobacteriumBacteroides. Int J Syst Evol Microbiol 53, 81-85.

Nedashkovskaya, O. I., Kim, S. B., Lee, D. H., Lysenko, A. M., Shevchenko, L. S., Frolova, G. M., Mikhailov, V. V., Lee, K. H. \& Bae, K. S. (2005). Roseivirga ehrenbergii gen. nov., sp. nov., a novel marine bacterium of the phylum 'Bacteroidetes', isolated from the green alga Ulva fenestrata. Int J Syst Evol Microbiol 55, 231-234.

Nedashkovskaya, O. I., Kim, S. B., Shin, D. S., Beleneva, I. A. \& Mikhailov, V. V. (2007). Fulvivirga kasyanovii gen. nov., sp. nov., a novel member of the phylum Bacteroidetes isolated from seawater in a mussel farm. Int J Syst Evol Microbiol 57, 1046-1049.

Olsen, G. J., Woese, C. R. \& Overbeek, R. (1994). The winds of (evolutionary) change: breathing new life into microbiology. J Bacteriol 176, 1-6.

Paster, B. J., Ludwig, W., Weisburg, W. G., Stackebrandt, E., Hespell, R. B., Hahn, C. M., Reichenbach, H., Stetter, K. O. \& Woese, C. R. (1985). A phylogenetic grouping of the bacteroides, cytophagas, and certain flavobacteria. Syst Appl Microbiol 6, 34-42.

Raguénès, G., Christen, R., Guézennec, J., Pignet, P. \& Barbier, G. (1997). Vibrio diabolicus sp. nov., a new polysaccharide-secreting organism isolated from a deep-sea hydrothermal vent polychaete annelid, Alvinella pompejana. Int J Syst Bacteriol 47, 989-995.

Reichenbach, H. (1989). The order Cytophagales Leadbetter 1974, 99 ${ }^{\mathrm{AL}}$. In Bergey's Manual of Systematic Bacteriology, vol. 3, pp. 20112073. Edited by J. T. Staley, M. P. Bryant, N. Pfennig \& J. C. Holt. Baltimore: Williams \& Wilkins.

Saitou, N. \& Nei, M. (1987). The neighbour-joining method: a new method for reconstructing phylogenetic trees. Mol Biol Evol 4, 406-425.
Sakamoto, M., Suzuki, M., Umeda, M., Ishikawa, I. \& Benno, Y. (2002). Reclassification of Bacteroides forsythus (Tanner et al. 1986) as Tannerella forsythensis corrig., gen. nov., comb. nov. Int J Syst Evol Microbiol 52, 841-849.

Seo, H.-S., Kwon, K. K., Yang, S.-H., Lee, H.-S., Bae, S. S., Lee, J.-H. \& Kim, S.-J. (2009). Marinoscillum gen. nov., a member of the family 'Flexibacteraceae', with Marinoscillum pacificum sp. nov. from a marine sponge and Marinoscillum furvescens nom. rev., comb. nov. Int J Syst Evol Microbiol 59, 1204-1208.

Smibert, R. M. \& Krieg, N. R. (1994). Phenotypic characterization. In Methods for General and Molecular Bacteriology, pp. 607-654. Edited by P. Gerhardt, R. G. E. Murray, W. A. Wood \& N. R. Krieg. Washington, DC: American Society for Microbiology.

Suzuki, M., Nakagawa, Y., Harayama, S. \& Yamamoto, S. (2001). Phylogenetic analysis and taxonomic study of marine Cytophaga-like bacteria: proposal of Tenacibaculum gen. nov. with Tenacibaculum maritimum comb. nov. and Tenacibaculum ovolyticum comb. nov., and description of Tenacibaculum mesophilum sp. nov. and Tenacibaculum amylolyticum sp. nov. Int J Syst Evol Microbiol 51, 1639-1652.

Thompson, J. D., Gibson, T. J., Plewniak, F., Jeanmougin, F. \& Higgins, D. G. (1997). The CLUSTAL_X windows interface: flexible strategies for multiple sequence alignment aided by quality analysis tools. Nucleic Acids Res 25, 4876-4882.

Tindall, B. J. (1990a). A comparative study of the lipid composition of Halobacterium saccharovorum from various sources. Syst Appl Microbiol 13, 128-130.

Tindall, B. J. (1990b). Lipid composition of Halobacterium lacusprofundi. FEMS Microbiol Lett 66, 199-202.

Vandamme, P., Bernardet, J.-F., Segers, P., Kersters, K. \& Holmes, B. (1994). New perspectives in the classification of the flavobacteria: description of Chryseobacterium gen. nov., Bergeyella gen. nov., and Empedobacter nom. rev. Int J Syst Bacteriol 44, 827-831. 